\title{
BASIC RESEARCH ON COMPARISON OF WAVE GROWTH BETWEEN THE PACIFIC OCEAN AND THE SEA OF JAPAN DUE TO ATMOSPHERIC DEPRESSIONS FROM THE VIEWPOINT OF SHIP OPERATION
}

\author{
Kenji SASA ${ }^{1} \cdot$ Shinji MIZUI ${ }^{2} \cdot$ Toshihiko NAGAI ${ }^{3}$
}

\author{
${ }^{1}$ Member of JSCE, Dr. of Maritime Science, Lecturer, Hiroshima National College of Maritime Technology \\ (4272-1, Higashino, Osakikamijima-cho, Toyota-gun, Hiroshima 725-0231 JAPAN) \\ 2 Non-Member, Dr. of Maritime Science, Professor, Hiroshima National College of Maritime Technology \\ (4272-1, Higashino, Osakikamijima-cho, Toyota-gun, Hiroshima 725-0231 JAPAN) \\ $3^{3}$ Member of JSCE, Dr. of Engineering, Head, Marine Information Division, Port and Airport Research Institution \\ (3-1-1, Nagase, Yokosuka, Kanagawa, 239-0826 JAPAN)
}

\begin{abstract}
太平洋や日本海など外洋に面した海域に多くの港湾が運用されているが，台風期だけでなく冬季から春 季にかけても船舶の運用が低気圧の影響で困難となることがある。特に太平洋沿岸では日本の東方海上で 発達した低気圧から伝播する波浪が船舶運用に与える影響を詳細に分析した事例は少ない. 本研究では冬 季荒天時におけるナウファスの波浪観測データと天気図を様々な角度から分析し, まず日本海側と太平洋 側での波浪の発達傾向を比較した. さらに低気圧の進行パターン, 気圧差, 気圧傾度, 位置関係などとの 変化傾向と比較を行い，これらの波浪発達との関係についていくつかの知見が得られた.
\end{abstract}

Key Words : Atmospheric Depression, NOWPHAS, Wave Growth, Ship Operation, Harbour

\section{I.IN'TRODUCTION}

Recently, many studies of coastal waves or moored ship motions in harbours facing the open seas have been undertaken. Especially, long period waves are researched in detail from the viewpoint of harbour construction and ship operations. When a ship sails or moors in harbours, it is important to know oceanographic conditions beforehand. There are many studies on wave forecasting using various numerical methods, such as numerical and statistical models ${ }^{122}$. They allow highly accurate forecasts of oceanographic conditions, particularly as the performance of computers has improved in recent decades $^{3)}$. Ships often encounter with very dangerous situations when atmospheric depressions and typhoons develop near the Japanese islands from winter to spring. Mooring difficulties occur in some harbours facing the Pacific Ocean when atmospheric depressions grow ${ }^{4)}$. Such sea conditions make navigation so difficult as well as the mooring.
However, there are very few studies of waves from the viewpoint of ship operations. At first, some problems of ship operations are researched in case of atmospheric depressions. Some growing patterns of waves are analyzed in 10 observation points when atmospheric depressions are developing. Moving patterns of atmospheric depressions are analyzed from larger ranged weather charts when waves are growing in these observation points. This research reveals some distinct relationships between the waves and atmospheric depressions to predict the wave growth due to atmospheric depressions.

\section{IMPEDIMENTS TO MARINE NAVIGATION AND BERTH OPERATION DURING ATMOSPHERIC DEPRESSIONS}

Ships sometimes encounter severe conditions during atmospheric depressions in and around the Japanese islands. There are some specific patterns as atmospheric depressions develop in this area. The 
oceanographic conditions frequently impede shipping from winter to spring. The difficulties, which are associated with mooring in severe weather, sometimes cause accidents and even casualties. The primary difficulties that occur during mooring in the HA Port on the Pacific Ocean as a result of atmospheric depressions are shown in Table $1^{5(6) 7)}$. The operational troubles that occurred as a result of atmospheric depressions in the Sea of Japan are shown in Table 2.

Table 1 Mooring difficulties at the HA Port on the Pacific Ocean due to atmospheric depressions

\begin{tabular}{|c|l|c|c|c|l|}
\hline Year & $\begin{array}{l}\text { Month \& } \\
\text { Date }\end{array}$ & $\begin{array}{c}H_{1 / 3} \\
(\mathrm{~m})\end{array}$ & $\begin{array}{l}T_{1 / 3} \\
(\mathrm{~s})\end{array}$ & $\begin{array}{l}U_{\text {mean }} \\
(\mathrm{m} / \mathrm{s})\end{array}$ & $\begin{array}{l}\text { Ship } \\
\text { Type }\end{array}$ \\
\hline 1990 & $\begin{array}{l}\text { Dec. 21- } \\
22\end{array}$ & ---- & ---- & ---- & $\begin{array}{l}\text { Timber } \\
\text { Carrier }\end{array}$ \\
\hline 1991 & $\begin{array}{l}\text { Jan. 18- } \\
19\end{array}$ & 5.3 & 13.0 & 4.8 & $\begin{array}{l}\text { Timber } \\
\text { Carrier }\end{array}$ \\
\hline 1992 & $\begin{array}{l}\text { Mar. 31- } \\
\text { Apr. 1 }\end{array}$ & 3.1 & 12.5 & 3.7 & $\begin{array}{l}\text { Grain } \\
\text { Carrier }\end{array}$ \\
\hline 1996 & $\begin{array}{l}\text { Dec. 23- } \\
25\end{array}$ & 2.4 & $\begin{array}{l}16.4 \\
\mathrm{~s}\end{array}$ & 5.7 & $\begin{array}{l}\text { Ore } \\
\text { Carrier }\end{array}$ \\
\hline 1999 & $\begin{array}{l}\text { Dec. 20- } \\
21\end{array}$ & 1.9 & 12.0 & 3.0 & $\begin{array}{l}\text { Ore } \\
\text { Carrier }\end{array}$ \\
\hline
\end{tabular}

Table 2 Operational troubles during atmospheric depressions in the Sea of Japan

\begin{tabular}{|c|c|c|c|c|c|}
\hline Year & $\begin{array}{c}\text { Month } \\
\text { \& Date }\end{array}$ & $H_{l / 3}$ & $T_{l / 3}$ & $U_{\text {mean }}$ & $\begin{array}{c}\text { Ship } \\
\text { Type }\end{array}$ \\
\hline 1995 & $\begin{array}{c}\text { Dec. } \\
23-25\end{array}$ & $8.0 \mathrm{~m}$ & $10.0 \mathrm{~s}$ & $25.0 \mathrm{~m} / \mathrm{s}$ & $\begin{array}{c}\text { Coal } \\
\text { Carrier }\end{array}$ \\
\hline 1997 & Jan. 4 & $4.0 \mathrm{~m}$ & $9.0 \mathrm{~s}$ & unknown & Tanker \\
\hline
\end{tabular}

The coal carrier encounters with rapidly growing oceanographic conditions during the mooring. The tanker was wrecked, then huge amounts of oil were diffused along coastal zones facing the Sea of Japan. Ships are usually recommended to evacuate to safety areas when typhoons approach to Japan. However, the recommendation is hardly announced to evacuate from harbour or to cancel the navigation at all even if atmospheric depressions develop so much as shown in such cases. In other words, ships continue to operate even in severe conditions.

\section{WAVE GROWTH AT SPECIFIC POINTS FACING THE PACIFIC OCEAN}

Attention is first given to significant waves undergoing transitions at ten points in Japan facing the Pacific Ocean and the Sea of Japan as shown in Fig. 1 Waves are observed every two hours for 20 minutes at these points in the NOWPHAS (Nationwide network Ocean Waves Port and HArbourS) system ${ }^{8)}$. The following wave growth patterns were analyzed for 10 cases, as shown in Table 4.

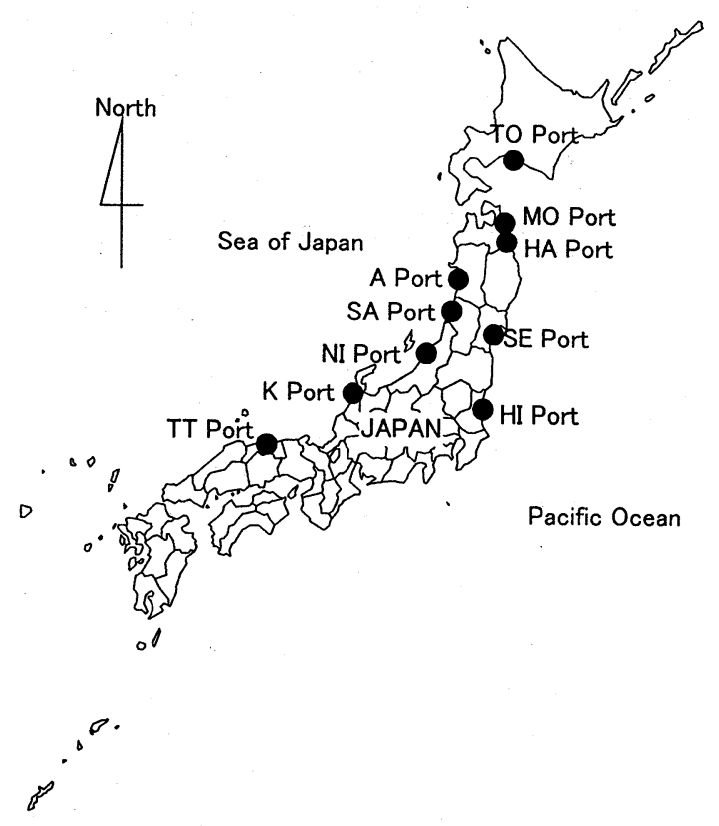

Fig.1 Observation points of waves

Table 4 Cases and periods of data analysis

\begin{tabular}{|c|c|c|}
\hline Case & Year & Month \& Date \\
\hline 1 & 1990 & December 19-22 \\
\hline 2 & 1991 & January 16-19 \\
\hline 3 & 1992 & March 29-April 1 \\
\hline 4 & 1995 & December 20-25 \\
\hline 5 & 1999 & December 17-20 \\
\hline 6 & 2000 & March 23-25 \\
\hline 7 & 1995 & January 24-31 \\
\hline 8 & 2000 & March 15-17 \\
\hline 9 & 2000 & March 18-21 \\
\hline 10 & 2001 & January 6-9 \\
\hline
\end{tabular}

Transitions of significant waves in Cases 2 are shown in Fig.2. These figures show that the growing patterns are quite different at each observation point. For example, wave heights do not increase at the SE Port. Values and rising points of wave heights are entirely different between the HA and HI Ports. It is common that wave periods become more than $10 \mathrm{~s}$ in any points. An operational report exists when the timber carrier was in the HA port. The captain of the timber carrier remained in the harbour too long after suspending cargo handling. Ships should not remain moored in the harbour when waves reach $4-5 \mathrm{~m}$ and $12 \mathrm{~s}$ for 12 hours. This indicates that the captain failed to judge the suitable timing of the operation in this emergency case. It is difficult for ship operators to make decisions based exclusively on their experience and intuition. 

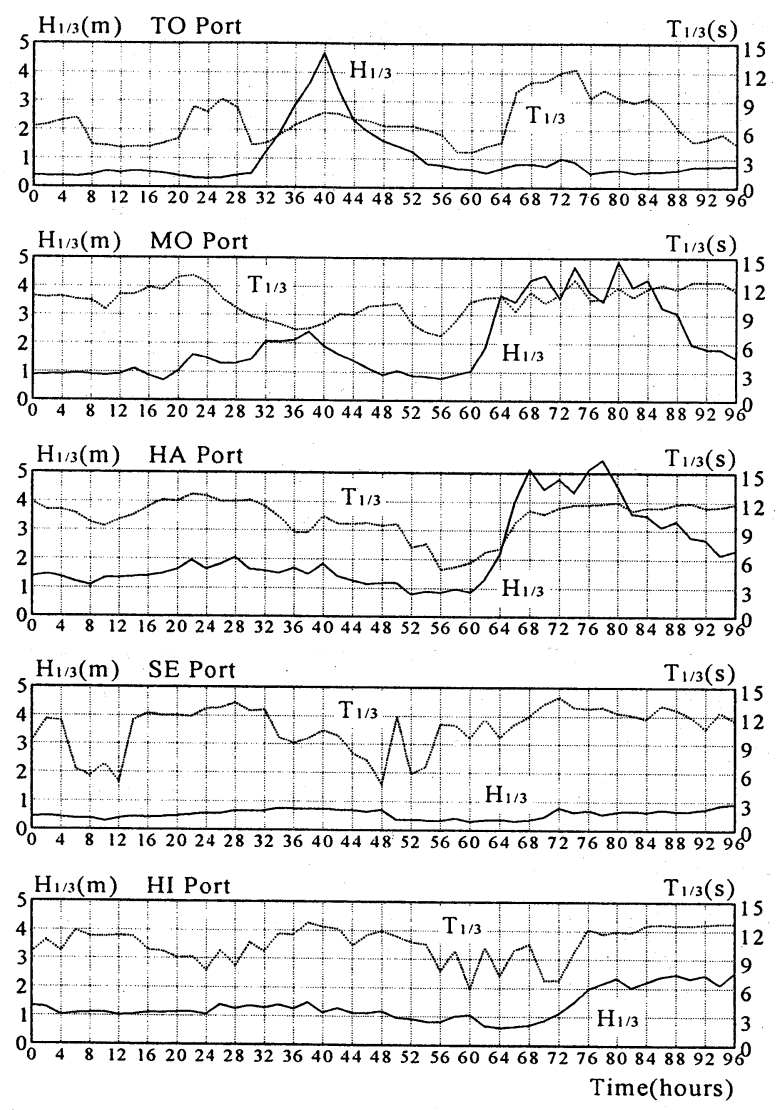

Fig.2(a) Transition of significant waves in points facing the Pacific Ocean(Case 2)
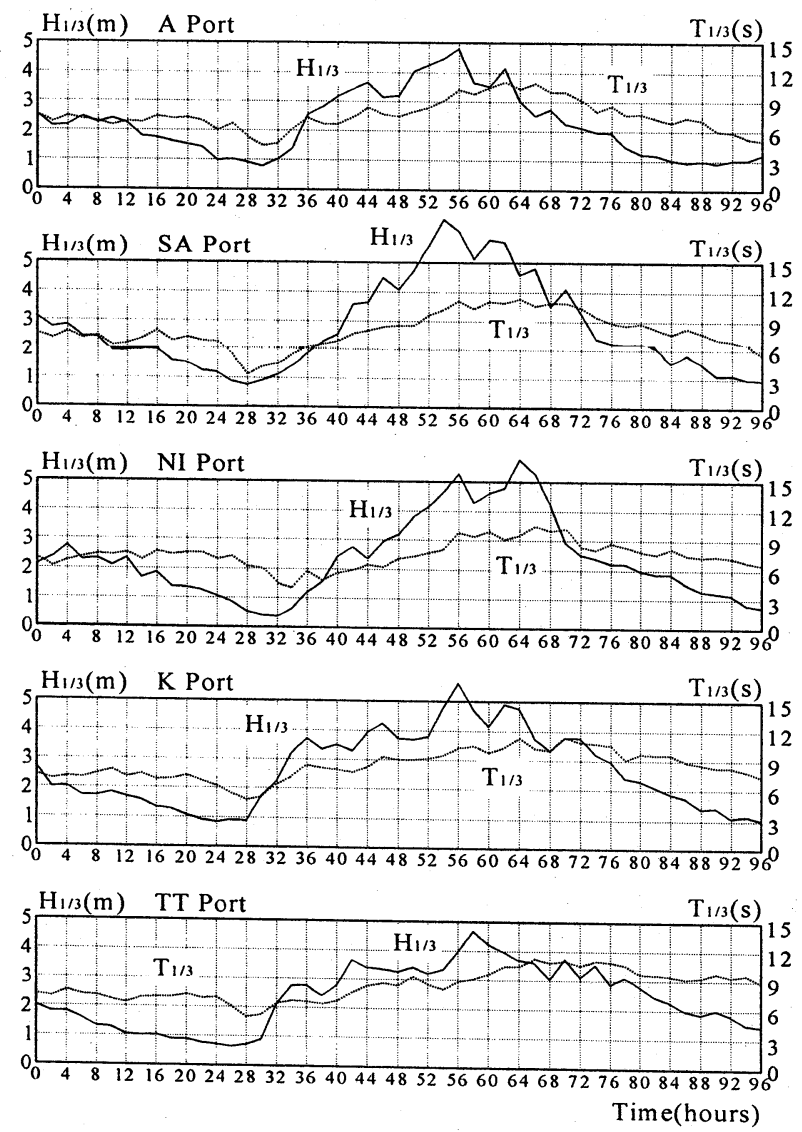

Fig.2(b) Transition of significant waves in points facing the Sea of Japan(Case 2)
It is obvious that rising points of wave heights and wave periods are 30-40 hours earlier in the Sea of Japan than them in the Pacific Ocean. In observation points facing the Sea of Japan, maximum wave heights are larger than those facing the Pacific Ocean. On the other hand, maximum wave periods are smaller. As shown in the figure, wave properties are pretty different between the Pacific Ocean and the Sea of Japan.

\section{ANALYSIS OF ATMOSPHERIC DEPRESSIONS FROM WEATHER CHARTS}

There are various patterns of wave growth that are influenced by atmospheric depressions. As those waves are generated by atmospheric depressions, it is necessary to research some of their parameters in detail. Then, larger ranged weather charts near Japan are analyzed every 6 hours in each case, as shown in Table 4. Fig.3 shows one sample of the weather charts in Case 2 (3:00 in Jan. 19, 1991).

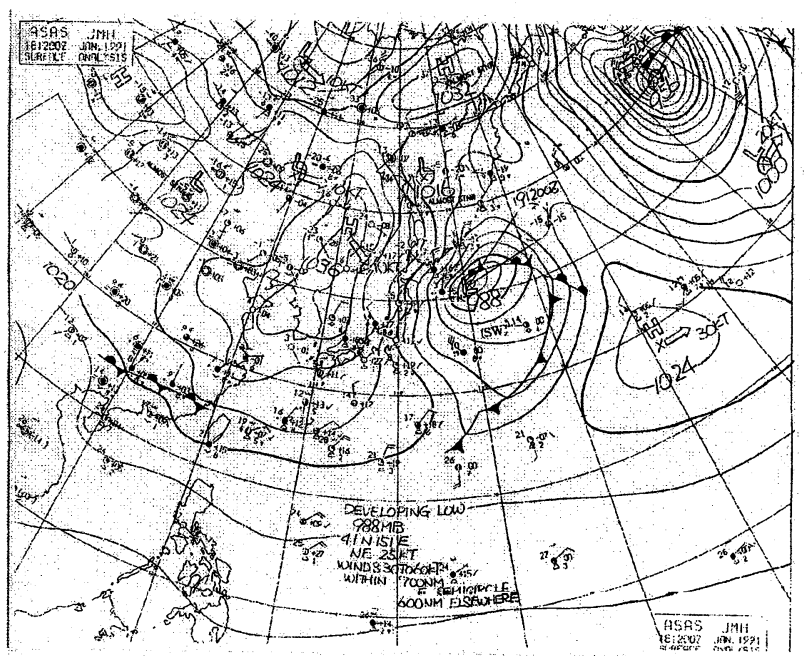

Fig.3 Weather chart in Case 2 (Jan. 19, 1991)

The atmospheric depression is developing to $988 \mathrm{hPa}$ in an eastern area of the Pacific Ocean. It is necessary to analyze the movement of atmospheric depressions in each case. As atmospheric depressions move over long distances and develop within shorter periods, transitions of parameters are necessary to research every 6 hours. Figs. 4 and 5 show the migration pathways of atmospheric depressions and anticyclones in Cases 2 and 3.

In Fig.4, two atmospheric depressions exist and move at the same time. One is moving easterly, and the other is moving northeasterly. These are eventually combining to the one atmospheric depression, which locates offshore of northern Japan.

In Fig.5, an atmospheric depression moves northeasterly. These are typical winter weather patterns in Japan. As the patterns seem to have a 
strong correlation with the wave growth patterns, they are categorized as shown in Fig.6.

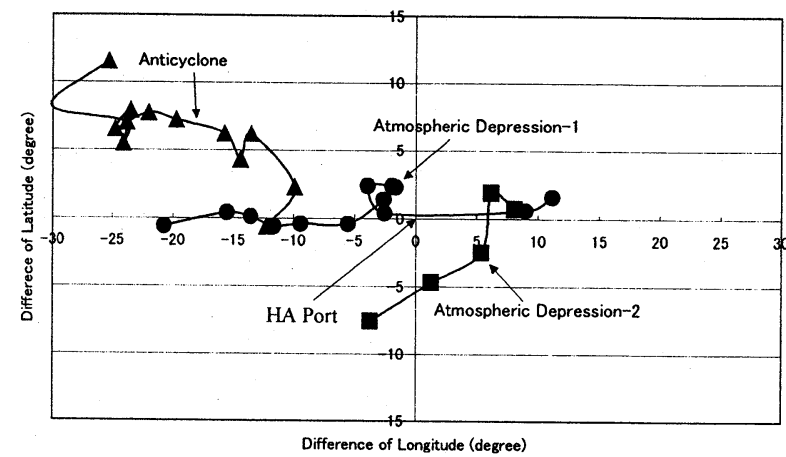

Fig.4 Routes of atmospheric depressions and anticyclones (Case 2)

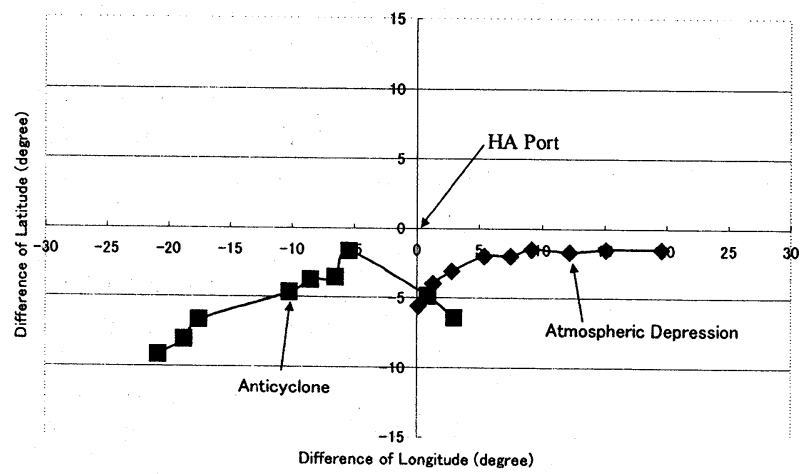

Fig.5 Routes of atmospheric depressions and anticyclones (Case 3)

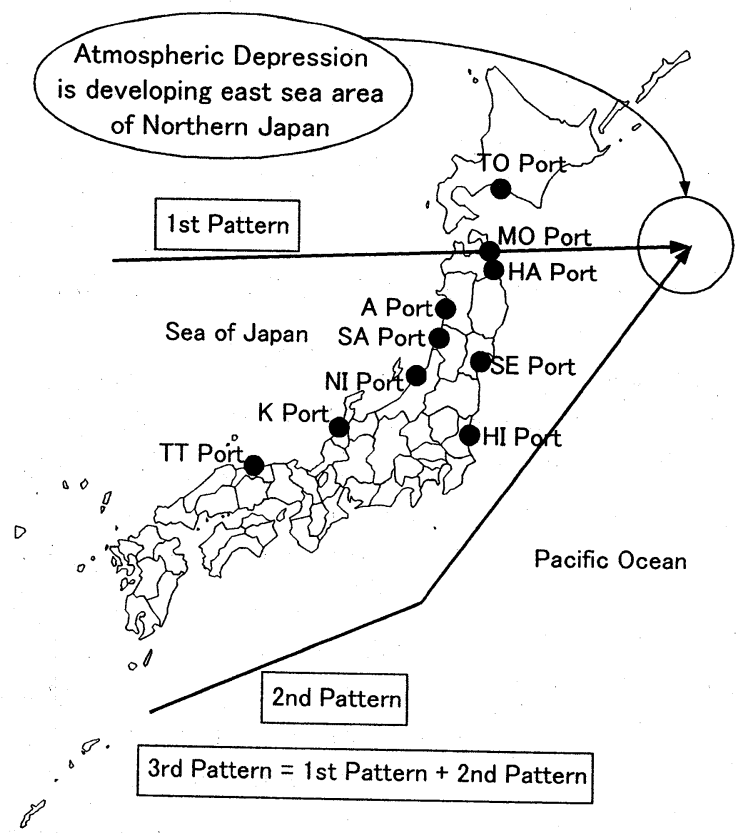

Fig.6 Categories of the moving patterns of atmospheric depressions

As shown in the figure, movement can be categorized into three patterns. The first is that the atmospheric depression moves east at almost the same latitude. The second is that it moves northeasterly in the Pacific Ocean. The third is a combination of the first and second patterns. The first pattern includes Cases 4, 6, and 9. The second includes Cases 1, 3, 7, 8, and 10. The third includes Case 2. It is necessary to research the statistical relationship between atmospheric depressions and significant waves in each case and for each pattern.

\section{COMPARISON OF GROWTH PATTERNS OF WAVES AND ATMOSPHERIC DEPRESSIONS}

In this chapter, some parameters are statistically analyzed to explain the phenomenon of the wave growth due to atmospheric depressions. The growth of waves is controlled by various parameters, such as atmospheric pressure, distance from an atmospheric depression, and bearing from the atmospheric depression. Wind speed is also strongly influenced by the barometric gradient. Here, the barometric gradient is calculated by the following equation.

$$
B G=\Delta P / \text { Dist }
$$

where $B G$ is the barometric gradient, $\triangle P$ is the difference of atmospheric pressures between the atmospheric depression and the observation point, and Dist is the distance between the atmospheric depression and the observation point. Fig.7 shows the comparison of growth patterns of some parameters between the SA Port and the HA Port. It shows that significant waves grow in completely different patterns in each sea area. In the SA Port, wave heights rapidly rise when atmospheric depressions approach there at very short distances. The value of the barometric gradient rapidly increases to $0.1 \mathrm{hPa} / \mathrm{km}$ at this point, too. This is the typical first pattern of atmospheric depressions. As strong winds may blow from west in the Sea of Japan, wind waves eventually grow to $4-6 \mathrm{~m}$. However, wave periods do not reach $10-15$ s because of the limited fetch in the Sea of Japan. On the other hand, wave heights are smaller in the HA Port than those in the SA Port. There are two rising points of wave heights. Wave periods are about $6-8 \mathrm{~s}$ at the first point, and they become $10-13 \mathrm{~s}$ at the second point. The first point is about $6-8 \mathrm{~s}$ of wave periods, and the second point is $10-13 \mathrm{~s}$. This may be influenced by longer fetch in the Pacific Ocean. The first rising point can be regarded as wind waves, which are happened 12 hours after the barometric gradient becomes the maximum value 0.07 . 

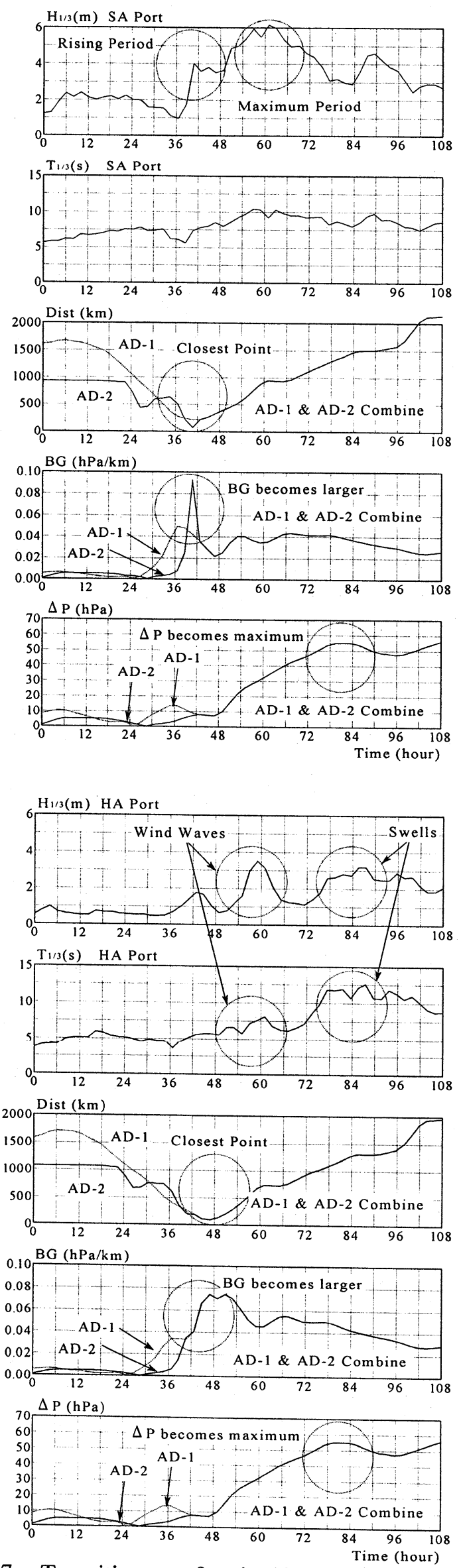

Fig.7 Transitions of significant waves and parameters of atmospheric depressions(Case 4, SA Port and HA Port)
The value of $\Delta P$ increases when the atmospheric depression locates $1000-2000 \mathrm{~km}$ offshore the HA Port. The second rising point can be regarded as swells, which propagate from the developed atmospheric depression. In the first pattern, the wind direction is from west to northwest. It is the same as the route of the atmospheric depression. The wave direction is almost the same as the wind direction, too. This weather condition makes larger wave heights. The wave direction is not necessarily corresponds with the wind direction because of the geometric conditions in the Pacific Ocean. Thus, the barometric gradient tends to influence the wave growth in the Sea of Japan so much. The propagation of swells is also rather influenced by the value of $\Delta P$ in the Pacific Ocean. It seems to be similar with swells which are propagated from typhoons. There are 20-30 hours of time differences of the wave growth between the SA Port and the HA Port. Fig.8 shows geometrical relations between observation points (SA Port and HA Port) and atmospheric depressions at each level of $H_{l / 3}$.
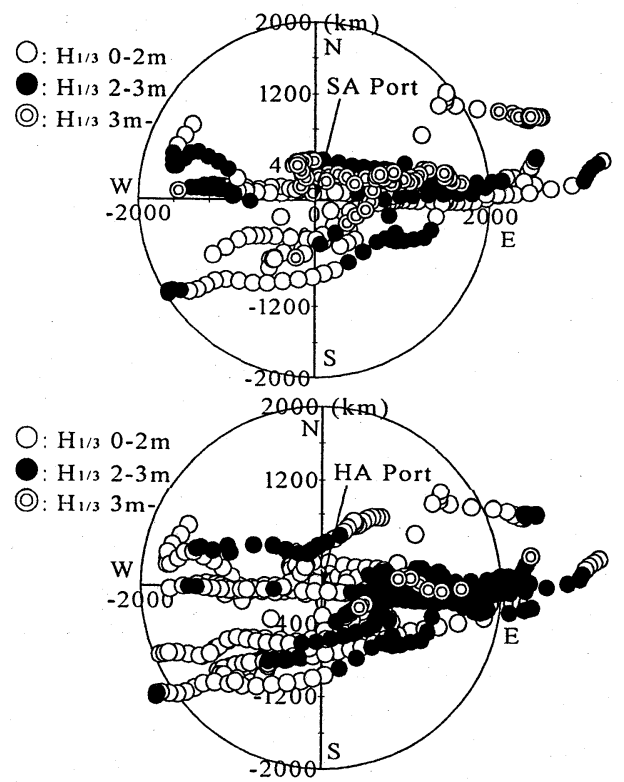

Fig.8 Geometrical relation of atmospheric depressions from SA Port and HA Port

This shows that the value of $H_{I / 3}$ exceeds $2 \mathrm{~m}$ when atmospheric depressions locate in the fourth and the first quadrants. However, the value of $H_{1 / 3}$ exceeds $2 \mathrm{~m}$ in some cases when they locate in the second or the third quadrants. Wave heights become more than $3 \mathrm{~m}$ when atmospheric depressions locate within $500-1,000 \mathrm{~km}$ from the SA Port. On the other hand, they often locate at a bearing of 0 degrees and a distance of $500-3,000 \mathrm{~km}$ from the HA Port. Growth patterns of waves are completely different between the Sea of Japan and the Pacific Ocean, 
although they are influenced by the same atmospheric depression. Especially, it is very important to know the rising point and the property of waves from the viewpoint of ship and port operation. In the Sea of Japan, the change rate of the barometric gradient influences to the growth of wind waves so much. In the Pacific Ocean, we have to give attentions to swells that are propagated from atmospheric depressions in east sea area, even if wind speeds are below $10 \mathrm{~m} / \mathrm{s}$. It is necessary to monitor the change of the position and the atmospheric pressure of atmospheric depressions, and the barometric gradient as well as the wave condition.

\section{CONCLUSIONS}

In this study, some parameters are researched on wave growth due to atmospheric depressions. The obtained results and future subjects are summarized below.

(1) Although there are many harbours in northern Japan that face the Pacific Ocean, ship operations sometimes feel quite difficult as a result of the waves caused by atmospheric depressions from winter to spring. However, recommendations of emergency evacuations are rarely made.

(2) Wave data were compared among 10 points when atmospheric depressions become remarkably strong. It is obvious that growth patterns of waves are so different between the Sea of Japan and the Pacific Ocean. In the Sea of Japan, most waves can be regarded as wind waves that are developed with strong winds in a limited fetch. In the Pacific Ocean, waves can be regarded as swells of 10-15s of wave periods with less wind in a longer fetch.

(3) There are three patterns of movement of atmospheric depressions in the cases analyzed. The first is that atmospheric depressions move easterly at almost the same latitude. The second is that they move northeasterly in the Pacific Ocean. The third is a combination of the first and the second patterns. The growth patterns of waves are so different in each moving pattern.

(4) Some related parameters of atmospheric depressions such as the barometric gradient, the difference of atmospheric pressure, the distance, and the bearing of them are analyzed in each case. It is found that the barometric gradient influences the growth of wind waves when the atmospheric depression approaches.

(5) Swells often propagate to harbours facing the Pacific Ocean when the difference of atmospheric depressions becomes more than $20-30 \mathrm{hPa}$. The barometric gradient does not influence to the propagation of swells so much.
(6) It will be necessary to construct a simplified prediction model of waves due to atmospheric depressions at these points from the viewpoint of safety for ships and harbours in the next study ${ }^{9}$.

\section{REFERENCES}

1) Suzuki, Y. and Isozaki, I.: On the Development of a Global Ocean Wave Model JWA3G, Proceedings of the Pacific Ocean Remote Sensing Conference in Melbourne, Australia, pp.195-201, 1994.

2)Hashimoto, N., Nagai, T., Shimizu, K. and Sugahara, K.: On the Reliability of the Statistical Wave Forecasting through Kalman Filering Combined with Principal Component Analysis, Report of Port and Harbour Research Institute, Vol.35, No.1, pp.91-115, 1996. (in Japanese)

3) Suzuki, Y. and Isozaki, I.: On the Development of a Global Ocean Wave Model JWA3G, Proceedings of the Pacific Ocean Remote Sensing Conference in Melbourne, Australia, pp.195-201, 1994.

4) Shiraishi, S., Nagamatsu, K., and Umihara, T.: Analysis of Fender Deformation by Moored Ship Motions Due to Wave Actions at Ocean Facing Port, Proceedings of the 9th International Offshore and Polar Engineering Conference, Vol.III, pp.582-589, 1999.

5) Shiraishi, S., Kubo, M., Ueda, S., and Sakakibara, S.: A Countermeasure by Mooring System for Moored Ship Motions under Long Period Waves, Proceedings of the 5th International Symposium of Coastal Ocean Space Ittilization, pp.207-216, 1996.

6)Kubo, M., Tsugane, M., Sasa, K., and Sakakibara, S.: Basic Research on Primary Factors that Controls Mooring Criteria -In Case of Ports Facing to Open Sea with Swells and Seasonal Winds-, Proceedings of the 8th International Offshore and Polar Engineering Conference, Vol.III, pp.603-610, 1998.

7) Sakakibara, S., Saito, K., Kubo, M., Shiraishi, S., Nagai, T., and Yazaki, F.: A Study on Long-Period Moored Ship Motions in a Harbour Induced by a Resonant Large Roll Motion Under Long-Period Waves, Proceedings of the 11th International Offshore and Polar Engineering Conference, Vol.III, pp.326-333, 2001.

8) Nagai, T., Sugahara, K., Hashimoto, N., Asai, T., Higashiyama, S., and Toda, K.: Introduction of Japanese NOWPHAS System and its Recent Topics, Proceedings of the International Conference on Hydro-Technical Engineering for Port and Harbor Construction, pp.67-82, 1994.

9) Sasa, K., Kubo, M., Shiraishi, S., and Nagai, T.: A Study on Prediction System of Critical Wave Conditions for Ship Mooring Against Typhoons, Coastal Engineering Journal, Vol.46, No.1, pp.6591, 2004. 